\title{
Effects of powder mixtures containing ark shell on IgE-mediated allergic response in $\mathrm{RBL}-2 \mathrm{H} 3$ cells
}

\author{
Mi Ja Chung ${ }^{1 *}$, Eun Goh ${ }^{1}$, So Hui Bae ${ }^{1}$, Sanghyun Lee $^{2}$, Jong Moon Hur ${ }^{3}$, \\ Goo Sang $\mathrm{Yoo}^{3}$, Deok Soon $\mathrm{Kim}^{3}$ \\ ${ }^{1}$ Department of Food Science and Nutrition, Gwangju University, Gwangju 61743, Korea \\ ${ }^{2}$ Department of Plant Science and Technology, Chung-Ang University, Anseong 17546, Korea \\ ${ }^{3}$ BeolgyoKKomak Co., Ltd., Boseong 59420, Korea
}

\section{꼬막 함유 혼합분말이 RBL-2H3 세포에서 IgE 매개 알레르기 반응에 미치는 영향}

\author{
정미자 $^{1 *} \cdot$ 고은 $^{1} \cdot$ 배소희 $^{1} \cdot$ 이상현 $^{2} \cdot$ 허종문 $^{3} \cdot$ 유구상 $^{3} \cdot$ 김덕순 $^{3}$ \\ ${ }^{1}$ 광주대학교 식품영양학과, ${ }^{2}$ 중앙대학교 식물생명공학과, ${ }^{3}$ (주)벌교꼬막
}

\begin{abstract}
The purpose of this study was to investigate the anti-allergic effects of a powder mixture containing ark shells (MP) on rat basophilic leukemia (RBL)-2H3 mast cells. When RBL-2H3 cells were sensitized with anti-dinitrophenyl (anti-DNP) IgE and subsequently stimulated with DNP-human serum albumin (HSA), $\beta$-hexosaminidase was released from the cells following degranulation of the activated mast cells. However, pretreatment with MP extract (MPCAS) before stimulation with DNP-HSA attenuated the release of $\beta$-hexosaminidase in IgE-antigen complex-stimulated RBL-2H3 cells. The levels of interleukin-4 (IL-4), IL-13, and TNF- $\alpha$ in the IgE-antigen complex-stimulated RBL-2H3 cells were measured using ELISA. Activated RBL-2H3 cells induced the expression of the abovementioned inflammatory cytokines that are critical for the pathogenesis of allergic diseases. MPCAS inhibited IL-4, IL-13, and TNF- $\alpha$ secretion from activated RBL-2H3 cells. In addition, the present study investigated the effects of MPCAS as an antigen on IgE-mediated activation of RBL-2H3 cells. When RBL-2H3 cells were sensitized with IgE and subsequently stimulated with MPCAS, $\beta$-hexosaminidase, IL-4, IL-13, and TNF- $\alpha$ levels did not change compared with those in the control. Thus, MPCAS does not act as an allergen in IgE-stimulated RBL-2H3 cells. These results indicate that MPCAS can be developed as an allergy-reducing food material by suppressing degranulation and inflammatory cytokine expression.
\end{abstract}

Keywords : ark shell, anti-allergic effect, allergic disease, antigen, RBL-2H3 cells

\section{서 론}

알레르기(allergy)란 자기면역질환의 하나로 생체 내에서 이물질이 방어기능을 가지기 위하여 항원에 대한 항체가 생 성되는데, 다시 항원이 체내에 들어왔을 때 항원과 항체가 복
합체를 형성하여 사람의 면역시스템이 과민하게 반응하여 병 적 현상을 유발하는 것을 말한다(Leung 등, 2004). 음식 알레 르기(food allergy)란 일부 단백질에 반응하여 무해한 특징 음식에 대해 우리 몸의 면역체계가 체내 유해한 것으로 판단 하여 이들 음식을 섭취했을 때 부적절하게 과민반응을 나타

*Corresponding author. E-mail : mijachung@gwangju.ac.kr, Phone : +82-62-670-2049, Fax : +82-62-670-2062

Received 07 July 2021; Revised 12 September 2021; Accepted 16 September 2021.

Copyright (c) The Korean Society of Food Preservation.

This is an Open Access article distributed under the terms of the Creative Commons Attribution Non-Commercial License (http://creativecommons.org/licenses/by-nc/4.0) which permits unrestricted non-commercial use, distribution, and reproduction in any medium, provided the original work is properly cited. 
내는 것이다. 식품 알레르기는 아토피피부염뿐만 아니라, 천 식, 두드러기, 아나필락시스, 소화기 증상 등 다양한 알레르 기 증상을 유발할 수 있다(Sicherer와 Sampson, 2018).

비만세포(mast cell)는 고친화성(high-affinity) immunoglobulin (Ig) E 수용체인 FceRI를 가지고 있고 IgE는 FceRI 수용체에 결합하여 $\mathrm{IgE}$ 매개 알레르기 반응을 개시한다. FceRI 수용체 에 $\mathrm{IgE}$ 와 항원이 복합체가 결합하면 $\beta$-hexosaminidase와 histamine 등이 방출되고, 여러 가지 사이토카인[interleukin-4 (IL-4), IL-13, rat tumor necrosis factor(TNF- $\alpha$ ) 등]과 염증매 개체(inflammatory mediators)를 방출하여 알레르기 질환 발병에 중요한 역할을 한다(Chung 등, 2020; Sicherer와 Sampson, 2018).

동물성 식품에 포함된 알레르기 유발 단백질 중 대표적인 단백질이 트로포미오신(tropomyosin: 근육조직에 포함된 단 백질)이다. 조개류는 알레르기를 유발하는 식품으로 알려져 있고, 조개류에 함유된 물질이 $\mathrm{IgE}$ 매개 반응으로 증상이 나 타날 수 있는 알레르겐(allergen) 중 하나가 트로포미오신 (tropomyosin)이며(Lopata 등, 2016), 이것은 꼬막의 주요 알레르 겐이기도 하다(Fujinoki 등, 2006). 트로포미오신(tropomyosin)은 열에 안전한 근육단백질로서 열을 가해도 없어지지 않으며, 트 로포미오신은 고도로 보존된 $\mathrm{IgE}$ 결합 에피토프( $\mathrm{IgE}$ binding epitopes)를 보유하고 있어 트로포미오신이 체내에 들어오면 면역세포가 과민하게 반응해 알레르기 반응이 나타난다 (Lopata 등, 2016). 이들 물질이 함유한 음식물을 만지기만 해도 반응이 나타날 수 있다. 검정콩 껍질 유래 안토시아닌, 다양한 플라보노이드(flavonoids), 키토산 등 천연소재들은 항알레르기 효과가 알려져 있고(Chung 등, 2011; Chung 등 2012; Chung 등, 2013; Chung 등, 2020), 이들 천연소재를 활용하여 제품화에 사용될 수 있는 알레르기 저감화 꼬막 함 유 식품소재 개발이 가능할 것으로 예상된다.

본 연구에서는 알레르겐으로 작용하는 꼬막 단백질의 불 활성화 하는 방법 및 다양한 천연소재들을 활용하여 꼬막의 알레르기를 저감화한 식품소재 개발에 대해 알아보았다. 천 연소재 함유 혼합물을 이용한 알레르기가 저감화된 초절임 꼬막을 활용하여 꼬막 함유 혼합분말 추출물 처리가 항원 (IgE)과 항체(DNP-HSA) 복합체에 의해 유도된 알레르기 유 발 호염기(basophil) RBL-2H3 비만세포에서 항알레르기 효 과 및 $\mathrm{IgE}$ 만 처리한 $\mathrm{RBL}-2 \mathrm{H} 3$ 세포 모델에서 알레르겐으로 작용하는지를 $\beta$-hexosaminidase 및 cytokines(IL-4, IL-13, $\mathrm{TNF}-\alpha)$ 분비능으로 알아보았다.

\section{재료 및 방법}

\section{초절임 꼬막 제조}

양파(onion), 사과(apple), 오이(cucumber), 생강(ginger) 및 브로콜리(broccoli)는 2020년 7월 광주광역시 남구 대형 마트
에서 국내산으로 구매하여 양파는 껍질을 제거하고, 다른 재 료는 껍질을 제거하지 않은 채 흐르는 물에 깨끗이 씻은 후 물기를 제거하고, $50^{\circ} \mathrm{C}$ 에서 건조 및 분쇄한 분말을 추출물 제 조에 사용하였다.

양파, 사과, 오이, 생강 및 브로콜리의 건조한 분말을 2:2:1:0.5:1 비율로 개발하여 20 배의 증류수를 넣은 후 $60^{\circ} \mathrm{C}$ 와 $60 \mathrm{rpm}$ 으로 맞추어진 shaking incubator(JSS1-100C, JSR, Seoul, Korea)에서 24시간 추출하여 커피 여과지로 여과한 추출물을 혼합물이라 하였다.

자숙 꼬막은 (주벌교꼬막으로부터 제공받았다. 사과식초 (Ottogi, Anyang), 백설 $5 \mathrm{~g}$ 스틱 설탕(Cheiljedang, Seoul) 및 소금(Hanju, Ulsan)은 광주광역시 남구 대형 마트에서 구매 하여 사용하였다. 꼬막 함유 혼합분말에 사용된 꼬막은 알레 르기 저감화 효과를 가진 초절임 꼬막을 사용하였다. 즉, 초 절임 꼬막 개발과정은 소독한 용기에 자숙 꼬막 $80 \mathrm{~g}$ 을 넣었 다. 그런 다음 물 $500 \mathrm{~mL}$ 에 소금 $20 \mathrm{~g}$ 과 설탕 $20 \mathrm{~g}$ 을 녹여 가열한 용액 중 $130 \mathrm{~mL}$ 를 더하였다. 그리고 혼합물 $30 \mathrm{~mL}$ 를 넣은 후 냉장고에서 2 시간 방치하였다. 2 시간 후 최종적으로 식초 $50 \mathrm{~mL}$ 를 더하여 냉장고에 18 시간 더 두었다. 그 후 1 차 초절임액을 HPLC 분석을 위해 모아 두고 2차 새로운 초절임 액을 첨가하였다. 2차 초절임 액은 물 $70 \mathrm{~mL}$ 에 소금 $5 \mathrm{~g}$, 설탕 $5 \mathrm{~g}$ 을 넣어 완전히 녹인 후 혼합물 $30 \mathrm{~mL}$ 를 추가하여 끓으면 바로 불을 끄고 2분간 방치 후 뜨거운 상태로 멸균된 유리 용기에 더했다. 식초 $50 \mathrm{~mL}$ 를 추가한 후 1 일간 냉장고 에 보관 후 실험에 사용하였고, 이 초절임 꼬막에 사용된 초 절임액을 2 차 초절임액이라고 하였다. 물을 혼합물 대신에 넣어 같은 방법으로 제조한 초절액 꼬막의 1 차와 2 차 초절임 액을 모아 대조군 초절임액으로 사용하였다.

1차 초절임액과 2차 초절임액은 합하여 Whatman filter paper No. 2(Whatman International Ltd., Springfield Mill, Kent, UK)를 사용하여 여과하였고, 감압농축기(R-100, BüCHI, Flawil, Switzerland)를 사용하여 용매를 제거한 후 동결건조 기(Clean vac 8, Hanil, Incheon, Korea)로 동결건조한 분말 을 플라보노이드 HPLC 분석용 시료로 사용하였다.

\section{초절임액에 함유된 플라보노이드 함량 분석}

동결건조 분말을 $40 \mathrm{mg}$ 을 취한 후 $100 \% \mathrm{MeOH}$ 에 용해하 여 $40 \mathrm{mg} / \mathrm{mL}$ 로 조제한 후 $(4,000 \mathrm{rpm})$ 초음파 진탕기로 20 분 간 녹인 후 $0.45 \mu \mathrm{m} \mathrm{PVDF}$ 멤브레인 필터로 여과하여 시험 용액으로 사용하였다. 분석에 사용된 HPLC system은 binary pump(Waters 1525, Waters Inc., Milford, MA, USA)와 UVVisible detector(Waters 2489, Waters Inc.)가 장착된 것으로 분석하였다. 컬럼은 YMC-Pack Pro $\mathrm{C}_{18} \operatorname{column}(25 \mathrm{~cm} \times 4.6$ $\mathrm{mm}, 5 \mu \mathrm{m}$; Waters Inc.)을 사용하여 분리를 진행하였다. 이 동상은 $0.5 \%$ acetic acid를 함유한 3차 증류수와 acetonitrile 
을 gradient 조건으로 두 용매 비율을 조정하면서 분석하였 다. 시료는 $20 \mu \mathrm{L}$ 를 주입하였고, 유속은 $1.0 \mathrm{~mL} / \mathrm{min}$ 으로 설 정하였으며, 모든 피크는 $360 \mathrm{~nm}$ 의 파장을 이용하여 검출 하였다. 이동상을 사용하기 전에 $0.45 \mu \mathrm{m}$ 필터(Millipore, Milford, MA, USA)를 통해 여과하고, 진공 하에 탈기하여 사용하였다.

\section{혼합분말에 함유된 식품 전처리 및 최적 배합비를 가진 꼬막 함유 혼합분말 개발}

혼합분말 개발을 위해 사용한 단호박, 브로콜리, 양파, 시 금치, 비트, 당근, 사과, 고구마, 귀리, 보리, 현미, 찰흑미, 찹 쌀, 검은콩 그리고 렌탈콩은 2020년 7-10월 광주광역시 남구 대형 마트에서 국내산으로 구매하였고, 월계수 잎(Gomaps, Sydney, Australia)은 순천 식자재 마트에서 구매하였다.

냉장고에 보관된 개발한 초절임 꼬막을 체로 건져 초절임 액을 완전히 제거한 후 $55^{\circ} \mathrm{C}$ 에서 건조하였다. 과채류로 단호 박, 브로콜리, 양파, 시금치, 비트, 당근 그리고 사과를 사용하 였고, 서류는 고구마를 사용하였다. 모두 씻어 물기를 제거하 였고, 브로콜리 $(15 \times 60 \times 5-20 \mathrm{~mm})$, 양파 $(45 \times 70 \times 5 \mathrm{~mm})$, 비트 $(50 \times 70 \times 5 \mathrm{~mm})$, 당근 $(50 \times 50 \times 5 \mathrm{~mm})$ 은 잘라 5 분간, 단호박 $(50 \times 60 \times 5 \mathrm{~mm})$ 과 고구마 $(50 \times 50 \times 5 \mathrm{~mm})$ 는 잘라 10 분간 찐 후 $55^{\circ} \mathrm{C}$ 에서 건조하였다. 사과 $(80 \times 35 \times 5 \mathrm{~mm})$ 는 씻어 물기를 제거한 후 잘라 둔 것을 $55^{\circ} \mathrm{C}$ 에서 건조하였다. 곡류인 귀리, 보리, 현미 그리고 찰흑미는 씻어 물기를 제거한 후 바람이 잘 통하는 실온에서 말린 후 귀리는 1 분 30 초간 그리고 다른 곡류는 2 분간 볶았다. 검정콩과 렌탈콩은 씻어 물기를 제거 한 후 하루 건조하였고, 검정콩은 6 분간 그리고 렌틸콩은 1 분 30 초간 볶았다. 아몬드와 호박씨는 오븐에서 $150^{\circ} \mathrm{C}, 8$ 분간 구웠다. 월계수 잎은 건조한 것을 구매하였고, 분쇄 후 상기 양파 등과 같은 조건으로 물추출 후 여과, 농축 후 동결건조 분말을 사용하였다.

혼합분말 제조를 위해 모든 시료는 각각 분쇄기(RT-08; Rong Tsong Precision Technoloy Co., Taiwan)를 이용하여 분쇄한 후, 꼬막 분말( $1 \%)$, 단호박 분말 $(5 \%)$, 브로콜리 분말 $(2 \%)$, 양파 분말(3\%), 시금치 분말(2\%), 비트 분말(1\%), 당 근 분말(1\%), 사과 분말(1\%), 고구마 분말(5\%), 귀리 분말 (3\%), 보리 분말(3\%), 현미 분말(3\%), 찰흑미 분말( $8 \%)$, 검 은콩 분말(7\%), 렌틸콩 분말(2\%), 아몬드 분말 $(6 \%)$, 호박씨 분말 $(6 \%)$, 월계수 잎 물 추출물 동결건조 분말(1\%) 그리고 말 토덱스트린(39\%)을 섞어 꼬막 함유 혼합분말(mixture powder containing ark shell, MP)을 개발하였다(Table 1). 다른 꼬막 함유 혼합분말의 식품 배합비는 Table 1과 같다.

\section{세포실험에 사용할 시료 준비}

Table 1의 배합비를 가진 MP, MP4 그리고 MP5를 각각
Table 1. The percent of food ingredients in powder mixtures containing ark shell

\begin{tabular}{|c|c|c|c|}
\hline \multirow{2}{*}{$\begin{array}{c}\text { Food ingredients } \\
(\%)\end{array}$} & \multicolumn{3}{|c|}{ Powder mixtures containing ark shell (MP) } \\
\hline & MP & MP4 & MP5 \\
\hline Ark shell & 1 & 1 & 1 \\
\hline Sweet pumpkin & 5 & 6 & 6 \\
\hline Broccoli & 2 & 2 & 1 \\
\hline Onion & 3 & 3 & 5 \\
\hline Spinach & 2 & 2 & 1 \\
\hline Beat & 1 & 1 & 1 \\
\hline Carrot & 1 & 1 & 1 \\
\hline Apple & 2 & 2 & 2 \\
\hline Aronia & - & 1 & 1.5 \\
\hline Sweet potato & 5 & 6 & 6 \\
\hline Oats & 3 & 3 & 3 \\
\hline Barley & 3 & 3 & 3 \\
\hline Brown rice & 3 & 3 & 3 \\
\hline Black rice & 8 & - & 2.5 \\
\hline Glutinous rice & - & 6 & 4 \\
\hline Black soybean & 7 & 6 & 6 \\
\hline Lentils & 2 & 2 & 1 \\
\hline Almond & 6 & 6 & 6 \\
\hline Pumpkin seed & 6 & 6 & 6 \\
\hline Bay leaf & 1 & - & - \\
\hline Maltodextrin & 39 & 40 & 40 \\
\hline Total $(\%)$ & 100 & 100 & 100 \\
\hline
\end{tabular}

중량의 20 배인 증류수를 넣은 후 $60^{\circ} \mathrm{C}$ 와 $60 \mathrm{rpm}$ 으로 맞추 어진 shaking incubator(JSSI-100C, JSR, Seoul, Korea)에서 24 시간 추출하였다. 추출한 것은 원심분리 후 상층액을 감 압농축기(R-100, BüCHI, Flawil, Switzerland)를 사용하여 추출 용매를 제거한 후 동결건조기(Clean vac 8, Hanil, Incheon, Korea)로 동결건조한 분말을 $-20^{\circ} \mathrm{C}$ 에서 보관하면서 세포실험에 사용하였다. MP, MP4 그리고 MP5 추출물들의 동결건조 분말을 각각 MPCAS, MPCAS4 그리고 MPCAS5 라고 명명하였다.

\section{$\mathrm{RBL}-2 \mathrm{H} 3$ 세포 배양}

RBL-2H3 세포(rat basophilic leukemia mast cells)은 한국 
세포주은행에서 구매하여 사용하였다. RBL-2H3 세포는 Dulbecco's Modified Eagle Medium(DMEM, Welgene)에 $10 \%$ fetal bovine serum(FBS), $1 \%$ penicillin/streptomycin을 첨가한 세포 배양액을 사용하여 $37^{\circ} \mathrm{C}$ 습윤한 $\mathrm{CO}_{2}$ 배양기 (5\% $\mathrm{CO}_{2} / 95 \%$ air)에서 배양하였다. 세포가 배양 접시의 $80 \%$ 정도 차면 phosphate-buffered saline(PBS, $\mathrm{pH}$ 7.4)으로 세포의 단층을 씻어내고, trypsin-EDTA $(\times 1)$ 를 처리하여 계 대 배양한 후 배지는 2 일마다 교환하였다.

\section{시료 처리}

RBL-2H3 세포를 $5 \times 10^{5}$ cells/well로 24-well plate에 분주 하여 48시간 배양한 후 FBS가 함유되지 않은 serum-free medium(SFM)으로 배지를 교환하여 2시간 동안 배양하였다. 이후 $250 \mathrm{ng} / \mathrm{mL}$ dinitropheny-Immunoglobulin E(DNP-IgE) 가 포함된 배지로 교환하여 24시간 동안 배양하였다. 세포를 Siraganian buffer $1(119 \mathrm{mM} \mathrm{NaCl}, 5 \mathrm{mM} \mathrm{KCl}, 0.4 \mathrm{mM}$ $\mathrm{MgCl}_{2}, 25 \mathrm{mM}$ PIPES, $\mathrm{pH}$ 7.2)로 세척 후 Siraganian buffer $2\left(119 \mathrm{mM} \mathrm{NaCl}, 5 \mathrm{mM} \mathrm{KCl}, 1 \mathrm{mM} \mathrm{CaCl}, 0.4 \mathrm{mM} \mathrm{MgCl}_{2}\right.$, $25 \mathrm{mM}$ PIPES, $5.6 \mathrm{mM}$ glucose, $0.1 \%$ bovine serum albumin, $\mathrm{pH}$ 7.2)로 10 분간 추가 배양하였다.

항알레르기 실험을 위해서 시험물질을 함유한 SFM으로 세포 배양액을 교환하여 2시간 배양하였다. 이후 $10 \mu \mathrm{g} / \mathrm{mL}$ 의 dinitrophenyl-human serum albumin(DNP-HSA)를 함유한 SFM으로 세포 배양액을 교환하여 2시간 동안 배양한 후 10 분간 얼음에서 냉각시켜 반응을 종결하였다. 시료가 알레르 겐(allergen)으로 작용하는지 알아보기 위해서는 DNP-HSA (항원) 대신 시료를 처리하였다.

세포 배양액을 수거하여 $\beta$-hexosaminidase 분비량 측정을 위해 $35 \mu \mathrm{L}$ 사용하고 남은 세포 배양액은 $5,000 \mathrm{rpm}$ 에서 10 분 동안 원심 분리하여 분리된 상층액을 $-20^{\circ} \mathrm{C}$ 에 보관한 후 cytokine 측정을 위한 시료로 사용하였다.

$\beta$-Hexosaminidase 분비량 측정 및 cytokine 측정을 위해 상층액을 수거한 후 남은 세포는 3-(4,5-dimethylthiazol-2-yl)2,5-diphenyltetrazolium bromide(MTT; Sigma-Aldrich Co., St Louis, MO, USA) 시약을 처리하여 세포 생존율을 확인하 였다.

\section{세포 생존율 측정}

세포 생존율은 Chung 등(2020)의 방법과 유사하게 MTT (Sigma-Aldrich Co.) 환원 방법을 이용하여 측정하였다. 즉, 각 well에 MTT 용액 $(5 \mathrm{mg} / \mathrm{mL})$ 을 성장 배지의 10 분의 1 을 가해주고 다시 $37^{\circ} \mathrm{C}$ 에서 4 시간 더 배양하여 MTT를 환원시 켜 생성된 formazan이 배지에 따라 나가지 않도록 배지를 조 심스럽게 제거하였다. 남아 있는 배지를 완전히 제거하기 위
해 실온에서 30 분간 방치한 후 dimethyl sulfoxide(DMSO; Sigma-Aldrich Co.)를 이용하여 용해한 시료를 $570 \mathrm{~nm}$ 에서 흡광도를 측정하였다. 흡광도 측정 시 공시료는 $\mathrm{DMSO}$ 로 하 였고, 세포의 생존율은 아래와 같이 계산하였다.

$$
\text { 세포 생존율(\%) }=\frac{\text { 시료 처리군의 흡광도 }}{\text { 대조군의 흡광도 }} \times 100
$$

\section{B-Hexosaminidase 분비량 측정}

96-well plate에 상층액 $35 \mu \mathrm{L}$ 와 substrate $\operatorname{buffer}(2 \mathrm{mM}$ 4- $p$-nitrophenyl- $N$-acetyl- $\beta$ - $D$-glucosaminide in $0.1 \mathrm{M}$ sodium citrate, $\mathrm{pH} 4.5) 35 \mu \mathrm{L}$ 를 넣어 $37^{\circ} \mathrm{C}$ 에서 1시간 동안 반응시킨 후 stop solution( $\left.0.1 \mathrm{M} \mathrm{Na}_{2} \mathrm{CO}_{3} / \mathrm{NaHCO}_{3}, \mathrm{pH} 10.0\right) 200 \mu \mathrm{L}$ 를 첨가하여 반응을 종결하고, $405 \mathrm{~nm}$ 파장에서 흡광도를 측 정하였다.

\section{Cytokines 함량 측정}

세포 배양액 내의 rat TNF- $\alpha$ (Abcam, Cambridge, MA, USA), rat IL-4(Thermo Fisher Scientific, Waltham, MA, USA) 및 rat IL-13(abcam) 함량은 각각의 ELISA kit을 사용 하여 제조회사가 제시한 방법에 따라 microplate reader (AMR-100, Allsheng Co., Ltd., Hangzhou, China)를 이용하 여 $450 \mathrm{~nm}$ 에서 흡광도를 측정하였다.

\section{통계처리}

본 실험 결과들은 평균(mean)士표준편차(standard deviation, $\mathrm{SD}$ )로 표시하였고, 실험군 간 평균의 차이는 one-way ANOVA 로 유의성을 확인한 후 Duncan's multiple range test를 이용 하여 사후 검정하였으며, $\mathrm{p}<0.05$ 수준에서 유의성의 여부를 검 증하였다. 모든 통계 분석은 Statistical Package for the Social Science (SPSS) version 17.0 프로그램(SPSS Inc., Chicago, IL, $\mathrm{USA})$ 을 이용하여 분석하였다.

\section{결과 및 고찰}

\section{꼬막 초절임에 사용된 초절임액의 플라보노이드 분석}

꼬막 함유 혼합분말 개발에 사용할 꼬막 초절임 개발을 위 해 먼저 혼합물과 초절임액을 개발하였다. 양파, 사과, 오이, 생강 그리고 브로콜리의 건조한 분말을 2:2:1:0.5:1 비율로 개발한 혼합물을 이용하여 초절임액을 개발하였고, 이들 초 절임액의 기능 성분을 분석한 결과는 Fig. 1과 같다.

혼합물은 fisetin은 흔적량(trace), kaempferol은 $2.1 \mu \mathrm{g} / \mathrm{g}$ extract, isoquercitrin은 $23.1 \mu \mathrm{g} / \mathrm{g}$ extract 그리고 spiraeoside 함량은 $31 \mu \mathrm{g} / \mathrm{g}$ extract이었다(Chung 등, 2020). 이들 혼합물 


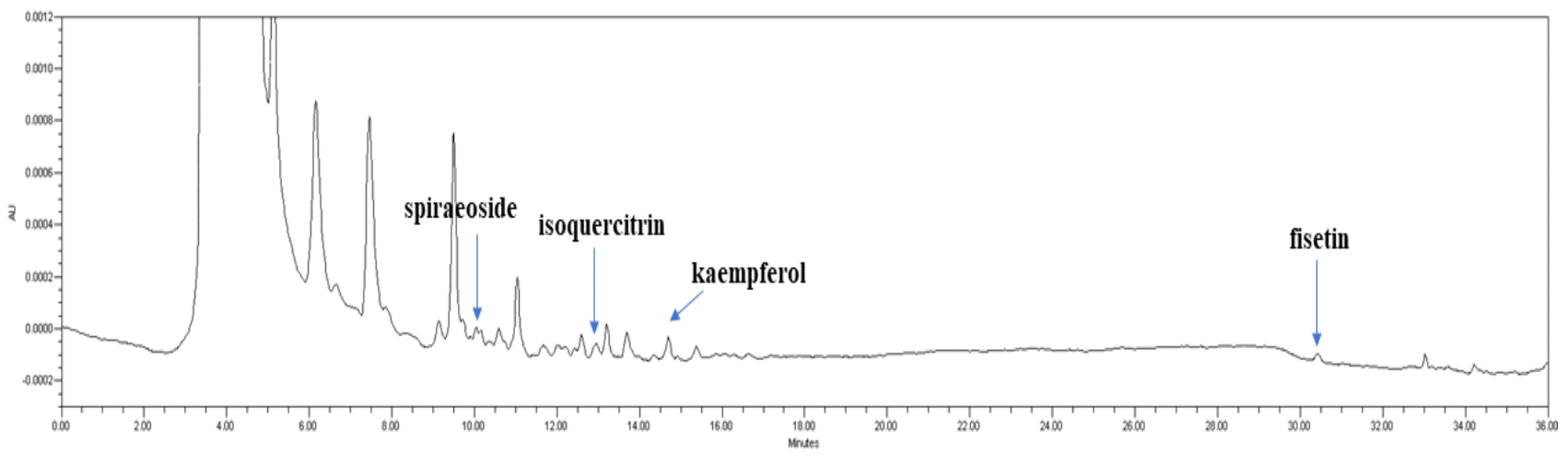

Fig. 1. HPLC-UV chromatograms of solution from ark shell vinegar pickle containing mixture.

Mixture is water extract of $2 \mathrm{~g}$ onion, $2 \mathrm{~g}$ apple, $1 \mathrm{~g}$ cucumber, $0.5 \mathrm{~g}$ ginger and $1 \mathrm{~g}$ broccoli.

을 이용하여 초절임액을 개발하였고, 이들 초절임액으로 꼬 막 초절임을 개발하였다. 꼬막 초절임을 개발하는 과정에서 1 차 초절임액과 2차 초절임액을 모아 함유된 플라보노이드 를 분석한 결과, fisetin, kaempferol, isoquercitrin 그리고 spiraeoside 함량은 피크가 작게 보이지만, 함량 계산이 불가 한 흔적량(trace) 검출되었다(Fig. 1). 꼬막 초절임의 꼬막에 함유된 fisetin, kaempferol, isoquercitrin 그리고 spiraeoside 함량도 흔적량(trace) 검출되었다(결과 미제시).

이는 식초에 의해 이들 물질이 모두 파괴되었을 것으로 추 정된다. 따라서 혼합물에 의한 저감화 효과를 얻기 위해서는 본 연구에서와 같이 식초를 넣기 전에 혼합물에 침지하는 과 정이 수행되어야 할 것으로 생각된다.

\section{$\operatorname{lgE}$ 처리한 RBL-2H3 세포에 꼬막 함유 혼합분말에 사용할} 초절임 꼬막이 $\beta$-hexosaminidase 분비에 미치는 영향

혼합물을 함유한 초절임액으로 제조한 꼬막 초절임으로부 터 꼬막 초절임액(개발과정 중 1차 초절임액과 2차 초절임액 을 합한 것)을 얻었다.

꼬막은 알레르겐(allergen), 즉 알레르기 항원으로 작용하여 알레르기를 유발할 수 있으므로 RBL-2H3 세포에 $\operatorname{IgE}$ (항체) 처리 후 꼬막 초절임 및 그것으로부터 얻은 꼬막 초절임액이 $\beta$-hexosaminidase 분비에 미치는 영향을 알아보았다(Fig. 2).

개발한 혼합물 함유 꼬막 초절임은 항원으로 작용하지 않 았고, 혼합물 대신 물을 더한 대조군 꼬막 초절임은 저농도에 서는 항원으로 작용하지 않았으나, $1,000 \mu \mathrm{g} / \mathrm{mL}$ 처리군에서 는 대조군과 비교하여 $\beta$-hexosaminidase 분비량이 유의적으 로 증가하였다(Fig. 2(A)).

꼬막 초절임의 제조공정에서 얻은 초절임액의 결과는, 대 조군 꼬막 초절임액과 혼합물 함유 꼬막 초절임액 모두 무처 리군인 대조군과 비교하여 유의적으로 $\beta$-hexosaminidase가 증
(A)

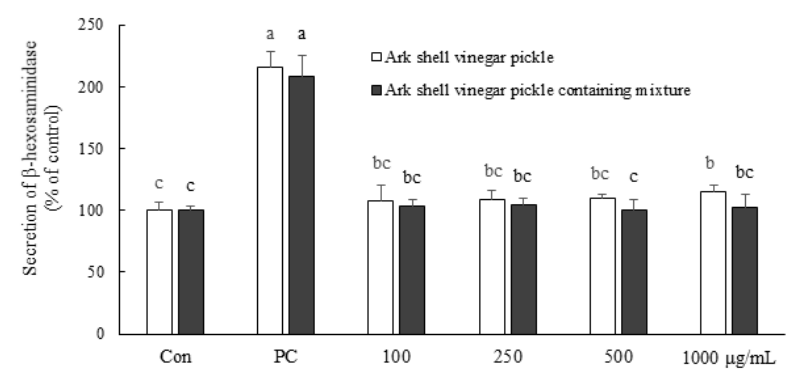

(B)

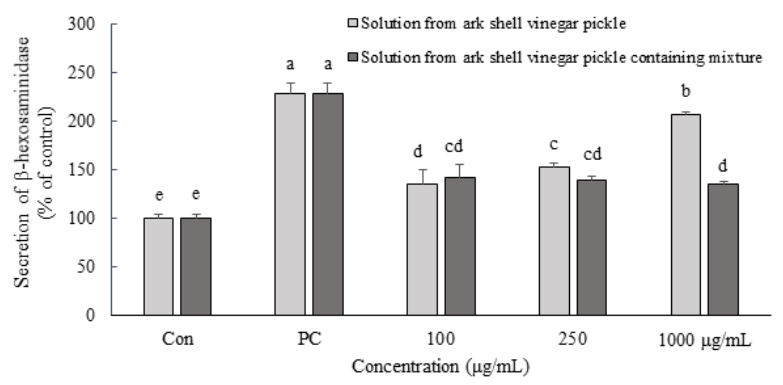

Fig. 2. Effects of ark shell vinegar pickle and it's solution on $\beta$ hexosaminidase release in IgE-treated RBL-2H3 cells.

Con (control), without DNP-HSA and sample; PC (positive control), $\mathrm{IgE}+\mathrm{DNP}-\mathrm{HSA}$. The values are expressed as mean $\pm \mathrm{SD}(\mathrm{n}=4)$; means with different letters significantly differ from each other $(p<0.05)$ as determined by Duncan's multiple range test.

가하였고, 특히 $1,000 \mu \mathrm{g} / \mathrm{mL}$ 대조군 꼬막 초절임액 처리군은 혼합물 함유 꼬막 초절임액보다 유의적으로 $\beta$-hexosaminidase 분비량이 증가하였다(Fig. 2(B)). 이와 같은 결과는 꼬막에 있는 항원 중 수용성인 물질이 있어 꼬막으로부터 용출되었 으나, 혼합물을 함유한 초절임액은 식초 없이 담가 둔 시간 동안 혼합물에 함유된 생리활성 물질이 이들 물질을 제거하 
였을 것으로 추정된다. 혼합물을 더하지 않은 대조군 꼬막 초 절임액 저농도 처리군은 무처리군인 대조군보다 유의적으로 높게 $\beta$-hexosaminidase을 분비하였지만, 혼합물 함유 초절임 액과 비교하여 유의적 차이가 없고, 식초 없이 자숙 꼬막만 담가 둔 물보다 $\beta$-hexosaminidase의 분비량이 감소되어(결과 미제시), 식초가 알레르기 유발 물질인 항원을 일부 불활성화 및 파괴할 수 있을 것으로 추정된다.

식품 알레르기는 음식물에 의해 일어나는 알레르기 반응 으로 꼬막 등에 의해 일어날 수도 있다. 즉, 꼬막에 있는 단백 질 등이 항원으로 인식한 $\mathrm{IgE}$ 항체가 비만세포에 결합하면 활성화된 비만세포가 히스타민 등을 방출해 염증 반응을 일 으켜 알레르기 증상을 일으킨다(Fujinoki 등, 2006). 비만세 포는 알레르기의 주 요인이 되는 면역세포로서, 비만세포라 고 불리는 이유는 핵에 비해 세포질이 많고 세포질 내에 과립 을 많이 갖고 있기 때문이다. 따라서 알레르기 비만세포 모델 로 호염기 세포(basophils) RBL-2H3 세포가 많이 사용되고 있다(Chen 등 2012; Passante와 Frankish, 2009). 또한, 이들 비만세포가 활성화되었을 때 분비되는 히스타민 농도가 낮아 히스타민과 함께 분비되는 $\beta$-hexosaminidase 활성을 측정함 으로써 탈과립 정도를 알 수 있다(Chung 등, 2011; Wendeler 과 Sandhoff, 2009).

$\mathrm{IgE}-$ 항원 복합체에 의해 감작된 RBL-2H3 세포에서 양파, 사과, 오이, 생강, 브로콜리 추출물은 무처리군인 대조군과 비 교하여 농도 의존적으로 $\beta$-hexosaminidase 분비량이 감소하였 고, 특히 양파와 생강 추출물 처리로 강하게 $\beta$-hexosaminidase 분비가 억제되었다(Chung 등, 2020). Fisetin, kaempferol, isoquercitrin 그리고 spiraeoside은 항알레르기 효과에 대한 보 고가 있어(Chung 등, 2020; Hwang 등, 2018; Kim 등, 2015), 이들 물질들을 함유한 혼합물이 꼬막의 알레르기 저감화에 영향을 미쳤을 것으로 생각된다.

따라서 본 연구에서는 RBL-2H3 세포에 $\mathrm{IgE}$ 를 처리한 세 포 모델에서는 개발한 혼합물 함유 초절임 꼬막은 알레르겐 으로 작용하지 않아, 알레르기를 저감화시키는 꼬막 함유 혼 합분말 개발에 활용할 수 있다는 것을 확인하여 다음 개발을 진행하였다.

\section{lgE-antigen 복합체로 유도된 RBL-2H3 세포에서 3종류 의 꼬막 함유 혼합분말이 $\beta$-hexosaminidase release에 미치는 영향}

IgE-antigen 복합체로 유도된 RBL-2H3 세포에서 Table 1 에 제시된 배합비를 가진 혼합분말(mixture powder containing ark shell, MP), 혼합분말4(MP4) 그리고 혼합분말5(MP5)의 물 추출물들인 MPCAS, MPCAS4와 MPCAS5을 각각 처리 했을 때 $\beta$-hexosaminidase 분비능에 미치는 영향을 알아본

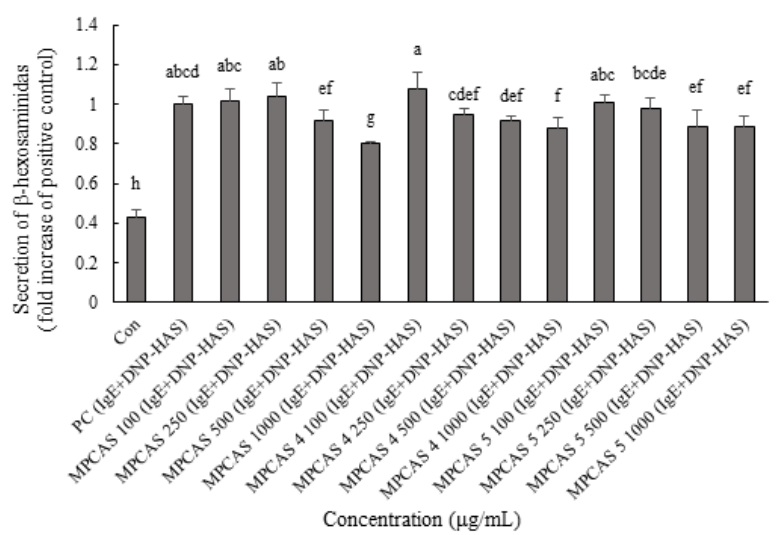

Fig. 3. Effects of the powder mixture extracts containing ark shell on $\beta$-hexosaminidase release in IgE-antigen complex-stimulated RBL-2H3 cells.

Con (control), without DNP-HSA and sample; PC (positive control), IgE+DNP-HSA. MPCAS, MPCAS4 and MPCAS5 were water extracts from MP, MP4 and MP5 in Table 1. The values are expressed as mean \pm SD $(n=4)$; means with different letters significantly differ from each other $(p<0.05)$ as determined by Duncan's multiple range test.

결과는 Fig. 3과 같다.

$500 \mu \mathrm{g} / \mathrm{mL}$ MPCAS, $1,000 \mu \mathrm{g} / \mathrm{mL}$ MPCAS, $1,000 \mu \mathrm{g} / \mathrm{mL}$ MPCAS4, $500 \mu \mathrm{g} / \mathrm{mL}$ MPCAS5 그리고 $1,000 \mu \mathrm{g} / \mathrm{mL}$ MPCAS5 처리군이 양성대조군(IgE+DNP-HSA)보다 유의적으로 $\beta$ hexosaminidase 분비능이 감소하였다(Fig. 3). $1,000 \mu \mathrm{g} / \mathrm{mL}$ 처리 농도에서 MPCAS가 MPCAS4와 MPCAS5보다 유의적 으로 $\beta$-hexosaminidase 분비능을 감소시켰고(Fig. 3), 관능검 사에서도 MPCAS가 가장 높은 점수를 받았으므로(결과 미 제시) 최적 배합비를 가진 혼합분말은 $\mathrm{MP}$ 를 선택하였다. 계 속되는 실험에서는 MPCAS를 꼬막 함유 혼합분말의 물 추출 물 동결건조 분말이라 하였고, MPCAS의 in vitro 항알레르기 및 알레르기 저감화 실험을 계속 진행하였다.

이들 MPCAS는 IgE-antigen 복합체로 유도된 RBL-2H3 세포에서 세포독성이 없었고, $\mathrm{IgE}$ 처리 RBL-2H3 세포에서 도 세포독성이 없었다(Fig. 4).

lgE-antigen 복합체로 유도된 알레르기 RBL-2H3 세포 및 $\operatorname{lgE}$-처리 RBL-2H3 세포에 꼬막 함유 혼합분말 추출물 처리에 의한 $\beta$-hexosaminidase 분비에 미치는 영향

계속되는 실험에 사용되는 꼬막 함유 혼합분말(mixture powder containing ark shell, MP)은 건조 초절임 꼬막과 함 께 다양한 생리활성 물질을 가진 건조 과채류(단호박, 브로콜 리, 양파, 시금치, 비트, 당근, 사과), 서류(고구마), 곡류(귀리, 보리, 현미, 찰흑미), 콩류(검정콩, 렌틸콩) 및 견과류(아몬드, 호박씨) 분말과 월계수 잎 물 추출물의 동결건조 분말의 혼합 
(A)

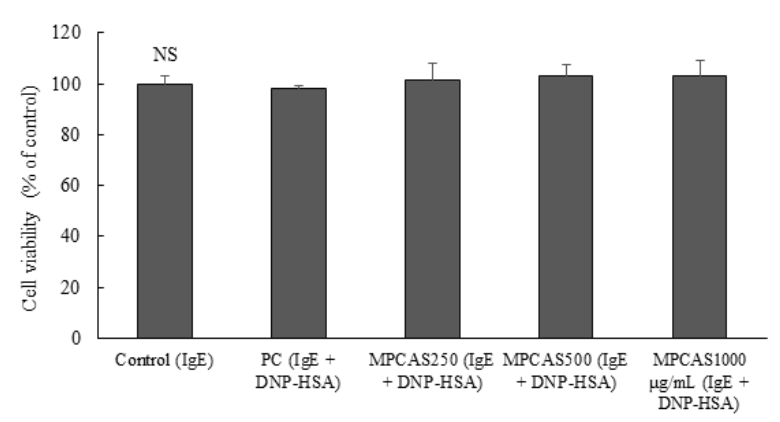

(B)

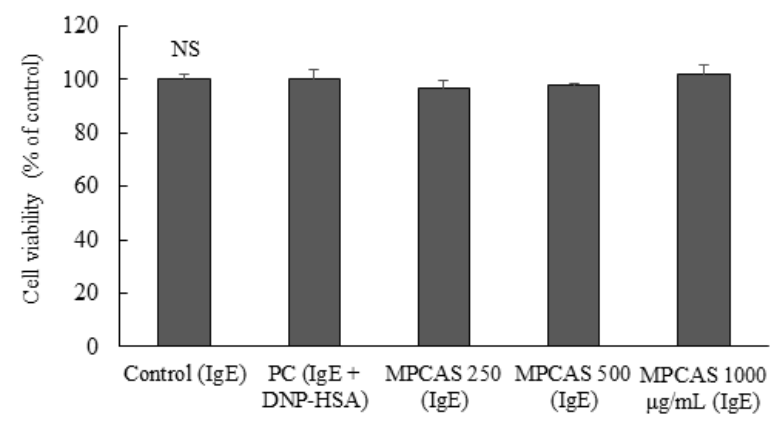

Fig. 4. Cytotoxicity of the powder mixture extracts containing ark shell on IgE-antigen complex-stimulated RBL-2H3 cells (A) and IgE-treated cells (B).

Con (control), without DNP-HSA and sample; PC (positive control), IgE + DNP-HSA. MPCAS was water extract from MP in Table 1 . The values are expressed as mean $\pm \mathrm{SD}(\mathrm{n}=4)$; NS, not significantly different from each other $(\mathrm{p}<0.05)$ as determined by Duncan's multiple range test.

물이다.

이들 혼합물을 물 추출하여 동결건조한 MPCAS 처리가 IgE-antigen 복합체로 유도된 RBL-2H3 세포의 세포 생존율 및 $\beta$-hexosaminidase release에 대한 영향(Fig. 4(A)와 Fig. 3) 을 알아보았다. 그리고 식품이 알레르겐(allergen)으로 작용 하는지 알아보는 세포 모델인 $\mathrm{IgE}$ 처리 RBL-2H3 세포에서 MPCAS 처리에 의한 세포 생존율 및 $\beta$-hexosaminidase release에 대한 영향(Fig. 4(B)와 Fig. 5)을 알아보았다.

IgE-antigen 복합체로 유도된 알레르기 RBL-2H3 세포에 서 MPCAS는 $1,000 \mu \mathrm{g} / \mathrm{mL}$ 처리군에서 양성대조군보다 유의 적으로 $\beta$-hexosaminidase 분비량이 감소하였다(Fig. 3). $\mathrm{IgE}$ 항 체를 처리한 RBL-2H3 세포에서 MPCAS는 $\beta$-hexosaminidase 분비량이 무처리군인 대조군과 비교하여 차이가 없었으므로 (Fig. 5) MPCAS는 항원으로 작용하지 않는다는 것을 알 수 있었다. 개발된 꼬막 함유 혼합분말은 항체인 $\mathrm{IgE}$ 가 감작된 상태에서 항원으로 작용하지 않고, 항알레르기 효과가 있다 는 것을 알 수 있었다.

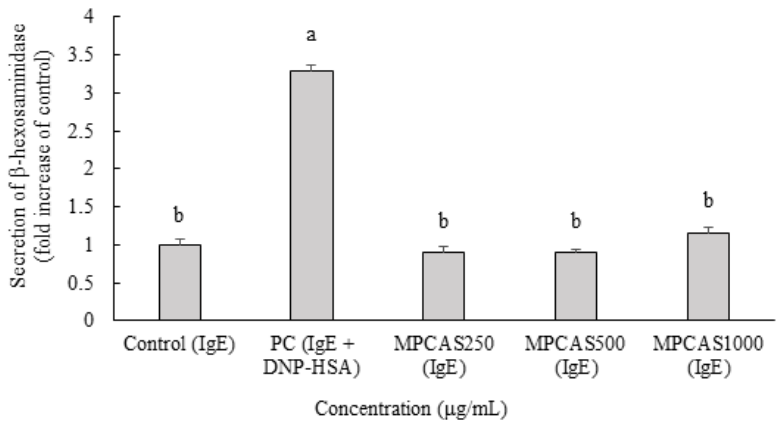

Fig. 5. Effects of the powder mixture extracts containing ark shell on $\beta$ - hexosaminidase release in IgE-treated RBL-2H3 cells.

Con (control), without DNP-HSA and sample; PC (positive control), IgE + DNP-HSA. MPCAS was water extract from MP in Table 1. The values are expressed as mean $\pm \mathrm{SD}(\mathrm{n}=4)$; means with different letters significantly differ from each other $(\mathrm{p}<0.05)$ as determined by Duncan's multiple range test.

lgE-antigen 복합체로 유도된 알레르기 RBL-2H3 세포 및 $\operatorname{lgE}$-처리 RBL-2H3 세포에 꼬막 함유 혼합분말 추출물 처리에 의한 cytokines(IL-4, IL-13, TNF- $\alpha$ ) 분비에 미 치는 영향

꼬막 함유 혼합분말 추출물인 MPCAS를 IgE+DNP-HSA (항원) 복합체에 의해 유도된 알레르기 RBL-2H3 세포 모 델에 처리한 결과, IL-4, IL-13 그리고 TNF- $\alpha$ 는 250,500 그리고 $1,000 \mu \mathrm{g} / \mathrm{mL} \mathrm{MPCAS}$ 처리군에서 양성대조군보다 유의적으로 감소하였다(Fig. 6(A), Fig. 7(A) 그리고 Fig. $8(\mathrm{~A})$ ). 따라서 MPCAS는 항알레르기 효과가 있다는 것을 알 수 있었다.

꼬막은 IgE-처리 RBL-2H3 세포에서 알레르겐(allergen)으 로 작용하여 과량의 $\beta$-hexosaminidase, IL-4, IL-13 그리고 $\mathrm{TNF}-\alpha$ 를 분비한다(결과 미제시). 따라서 꼬막을 소량 함유하 여도 알레르기를 유발할 수 있으므로 꼬막 함유 혼합분말 MPCAS가 알레르겐으로 작용하는지 알아보았다. $\mathrm{IgE}$ 를 처 리한 RBL-2H3 세포에 MPCAS를 처리한 결과, IL-4, IL-13 그리고 TNF- $\alpha$ 함량이 무처리군은 대조군과 유사하였다(Fig. 6(B), Fig. 7(B) 그리고 Fig. 8(B)). 이와 같은 결과들은 MPCAS 에 함유한 꼬막 및 다른 혼합물도 알레르겐으로 작용하지 않 는다는 것을 알 수 있었다.

항알레르기 효과가 있는 양파, 사과, 브로콜리, 검정콩 껍 질(Chung 등, 2011; Chung 등, 2020) 등과 제품개발을 위한 영양과 맛을 고려하여 더한 식물 건조 분말의 혼합물들에 꼬 막 건조 분말을 섞었을 때 이들 혼합분말은 항알레르기 효과 를 가지고 있으면서 알레르겐으로 작용하지도 않아 알레르기 반응을 걱정하는 소비자들에게 알레르기 저감화 식품소재로 활용할 수 있을 것으로 기대된다. 
(A)

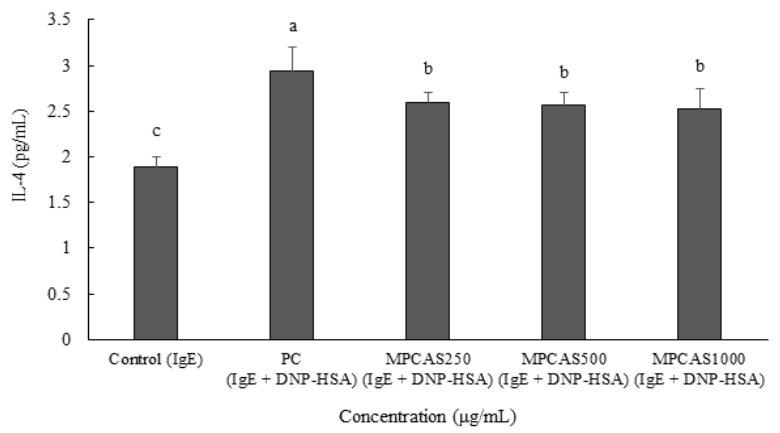

(B)

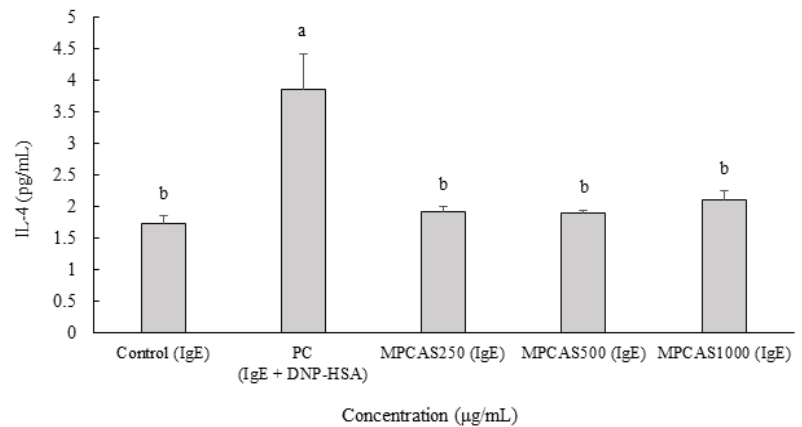

Fig. 6. Effects of the powder mixture extracts containing ark shell on the IL-4 protein levels in IgE-antigen complex-stimulated RBL-2H3 cells (A) and IgE-treated RBL-2H3 cells (B).

Con (control), without DNP-HSA and sample; PC (positive control), IgE + DNP-HSA. MPCAS was water extract from MP in Table 1. The values are expressed as mean $\pm \mathrm{SD}(\mathrm{n}=4)$; means with different letters significantly differ from each other $(\mathrm{p}<0.05)$ as determined by Duncan's multiple range test.

(A)

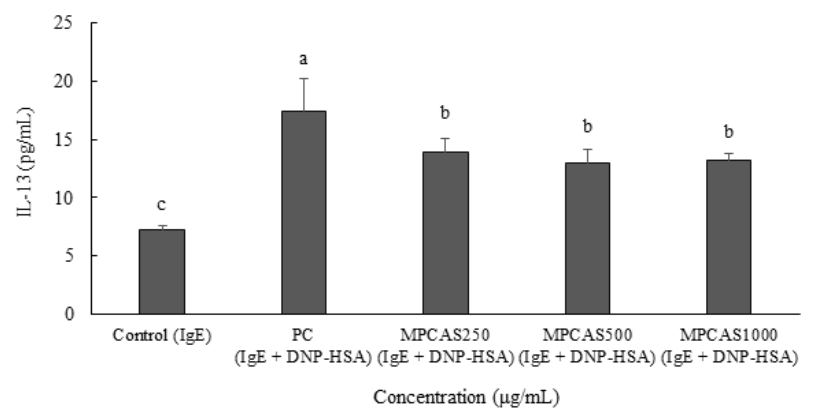

(B)

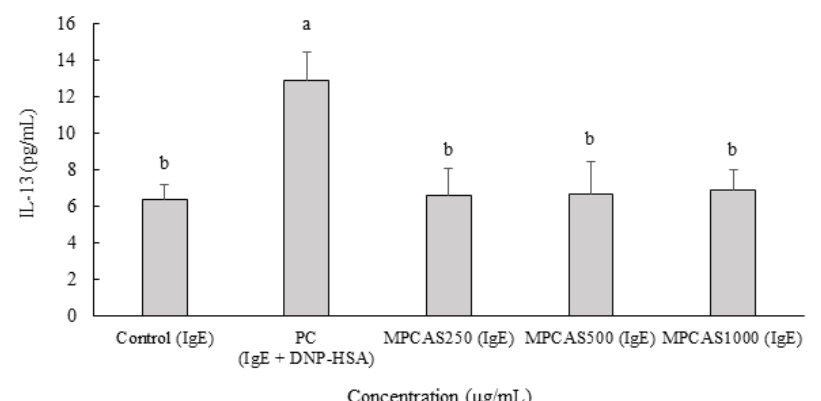

Fig. 7. Effects of the powder mixture extracts containing ark shell on the IL-13 protein levels in IgE-antigen complex-stimulated RBL-2H3 cells (A) and IgE-treated RBL-2H3 cells (B).

Con (control), without DNP-HSA and sample; PC (positive control), IgE + DNP-HSA. MPCAS was water extract from MP in Table 1. The values are expressed as mean $\pm \mathrm{SD}(\mathrm{n}=4)$; means with different letters significantly differ from each other $(\mathrm{p}<0.05)$ as determined by Duncan's multiple range test.

(A)

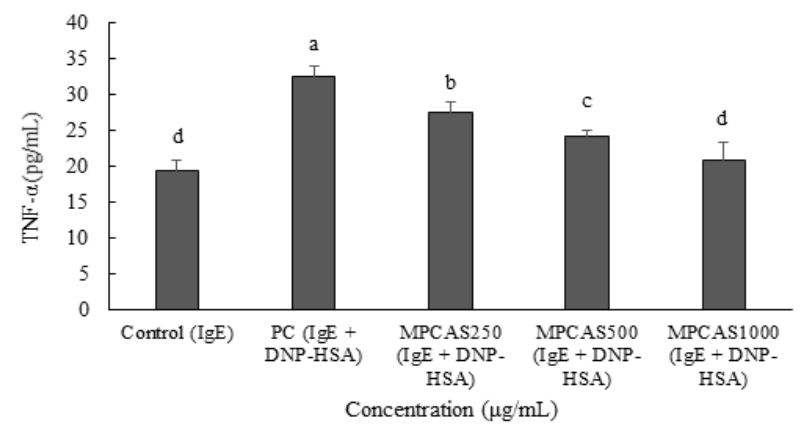

(B)

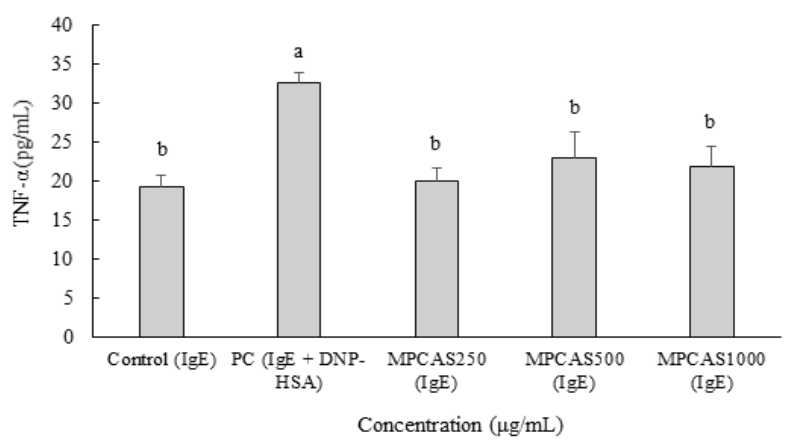

Fig. 8. Effects of the powder mixture extracts containing ark shell on the TNF- $\alpha$ protein levels in IgE-antigen complex-stimulated RBL-2H3 cells (A) and IgE-treated RBL-2H3 cells (B).

Con (control), without DNP-HSA and sample; PC (positive control), IgE + DNP-HSA. MPCAS was water extract from MP in Table 1. The values are expressed as mean $\pm \mathrm{SD}(\mathrm{n}=4)$; means with different letters significantly differ from each other $(\mathrm{p}<0.05)$ as determined by Duncan's multiple range test. 


\section{요 약}

본 연구의 목적은 비만세포인 RBL-2H3(rat basophilic leukemia cell line) 세포에서 꼬막 함유 혼합분말(MP)의 항 알레르기 효과를 연구하는 것이다. RBL-2H3 세포를 antidinitrophenyl(anti-DNP) $\mathrm{IgE}$ 로 감작시킨 후 DNP-human serum albumin(HSA)으로 자극하면 활성화된 비만세포는 탈 과립으로 $\beta$-hexosaminidase가 과량 방출되었다. 그러나 $\operatorname{IgE}$ 로 감작시킨 RBL-2H3 세포에 DNP-HSA를 자극하기 전에 $\mathrm{MP}$ 추출물(MCAS)을 전처리하면 IgE-항원 복합체로 자극된 $\mathrm{RBL}-2 \mathrm{H} 3$ 세포에서 $\beta$-hexosaminidase의 방출이 감소하였다. $\mathrm{IgE}-$ 항원 복합체에 의해 감작된 $\mathrm{RBL}-2 \mathrm{H} 3$ 세포에서 Interleukin-4(IL-4), IL-13 그리고 TNF- $\alpha$ 함량을 ELISA로 측정하였다. 활성화된 RBL-2H3 세포는 알레르기 질환의 발 병에 중요한 염증성 사이토카인(IL-4, IL-13 및 TNF- $\alpha$ )의 발 현을 유도하였다. MPCAS는 활성화된 RBL-2H3 세포에서 $\mathrm{IL}-4, \mathrm{IL}-13$ 및 TNF- $\alpha$ 의 분비를 억제하였다. 또한, 본 연구는 $\mathrm{RBL}-2 \mathrm{H} 3$ 세포의 IgE 매개 활성화에 대한 MPCAS이 항원으 로 작용하여 알레르기를 유발할 수 있는지 알아보았다. $\mathrm{RBL}-2 \mathrm{H} 3$ 세포를 $\mathrm{IgE}$ 로 감작시킨 후 MPCAS로 자극했을 때 $\beta$-hexosaminidase, IL-4, IL-13 및 TNF- $\alpha$ 수준은 대조군과 비교하여 변하지 않았다. 따라서 MPCAS는 IgE 자극 RBL$2 \mathrm{H} 3$ 세포에서 알레르겐(allergen)으로 작용하지 않았다. 이들 결과들은 MPCAS가 탈과립 및 염증성 사이토카인 발현 억제 를 통해 알레르기 감소 식품소재로 개발 가능하다는 것을 시 사하고 있다.

\section{감사의 글}

본 성과물은 중소벤처기업부에서 지원하는 "2020년도 지역 특화산업육성+(R\&D)-지역스타기업육성 사업(No. S2868121)" 의 연구수행으로 인한 결과물임을 밝힙니다.

\section{Conflict of interests}

The authors declare no potential conflict of interest.

\section{ORCID}

Mi Ja Chung https://orcid.org/0000-0003-0816-1354

\section{References}

Chen BH, Hung MH, Chen YF, Chang HW, Yu ML, Wan L, Tsai FJ, Wang TP, Fu TF, Chiu CC. Anti-allergic activity of grapeseed extract (GSE) on RBL-2H3 mast cells. Food Chem, 132, 968-974 (2012)

Chung MJ, Ha TJ, Choi HN, Lee JS, Park YI. Inhibitory effects of anthocyanins isolated from black soybean (Glycine max L.) seed coat on degranulation and cytokine generation in RBL-2H3 cells. J Korean Soc Food Sci Nutr, 40, 1662-1667 (2011)

Chung MJ, Park JK, Park YI. Anti-inflammatory effects of low-molecular weight chitosan oligosaccharides in IgEantigen complex-stimulated RBL-2H3 cells and asthma model mice. Int Immunopharmacol, 12, 453-459 (2012)

Chung MJ, Sohng JK, Choi DJ, Park YI. Inhibitory effect of phloretin and biochanin A on IgE-mediated allergic responses in rat basophilic leukemia RBL-2H3 cells. Life Sci, 93, 401-408 (2013)

Chung MJ, Lee SH, Kim DS. Anti-allergic effects of onion, apple, cucumber, gingar, and broccoli mixtures and their bioactive compounds in RBL-2H3 cells. Korean J Food Preserv, 27, 973-983 (2020)

Fujinoki M, Ueda $M$, Inoue $T$, Yasukawa $N$, lnoue $R$, Takagi TI. Heterogeneity and tissue specificity of tropomyosin isoforms from four species of bivalves. Comp Biochem Physiol B: Biochem Mol Biol, 143, 500-506 (2006)

Hwang KA, Hwang YJ, Song J. Anti-allergic effect of Aster yomena on ovalbumin-sensitized mouse and RBL-2H3 cells via Th1/Th2 cytokine balance. J Funct Foods, 44, 1-8 (2018)

Kim JK, Seo YK, Park S, Park SA, Lim S, Lee S, Kwon O, Seo JK, Chol UK, Ryu SH, Suh PG. Spiraeoside inhibits mast cells activation and IgE-mediated allergic responses by suppressing phospholipase $\mathrm{C}-\gamma$-mediated signaling. Biochem Cell Biol, 93, 227-235 (2015)

Lopata AL, Tebbe JK, Kamath SD. Allergens and molecular diagnostics of shellfish allergy. Allergo J, 25, 24-32 (2016)

Passante E, Frankish N. The RBL-2H3 cell line: Its provenance and suitability as a model for the mast cell. Inflamm Res, 58, 737-745 (2009)

Sicherer SH, Sampson HA. Food allergy: A review and update on epidemiology, pathogenesis, diagnosis, prevention, and management. J Allergy Clin Immunol, 141, 41-58 (2018)

Wendeler M, Sandhoff K. Hexosaminidase assays. Glycoconjugate J, 26, 945-952 (2009) 